Fourth International Conference on Sustainable Construction Materials and Technologies http://www.claisse.info/Proceedings.htm

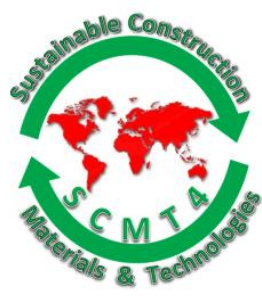

SCMT4

Las Vegas, USA, August 7-11, 2016

\title{
Development and Application of Concrete Using Seawater and By-product Aggregates
}

\author{
Keisaburo Katano $^{1 \mathrm{a}}$, Nobufumi Takeda ${ }^{1 \mathrm{~b}}$, Akira Shimmura ${ }^{2}$, Makoto Hisada ${ }^{3}$, and \\ Nobuaki Otsuki ${ }^{4}$
}

${ }^{1}$ Obayashi Corporation; Technical Research Institute - 4-640, Shimokiyoto, Kiyose-shi, Tokyo, Japan.

${ }^{1 a}$ Email: <katano.keisaburo@obayashi.co.jp>; ${ }^{1 b}$ Email:<takeda.nobufumi@obayashi.co.jp>

${ }^{2}$ Obayashi Corporation; Technical Department No.1, Civil Engineering Division, Tokyo Head OfficeShinagawa Intercity Tower B, 2-15-2, Konan, Minato-ku, Tokyo, Japan. Email: <shimmura.akira@obayashi.co.jp>

${ }^{3}$ Tohoku University; Department of Civil and Environmental Engineering - 6-6-06, Aramaki, Aoba-ku, Sendai, Japan. Email: 〈makoto.hisada.b4@tohoku.ac.jp>

${ }^{4}$ Tokyo Institute of Technorogy; Depertment of International Development Engineering - 2-12-1-S6-11 Ookayama, Meguro-ku,Tokyo, Japan,Email: 〈otsuki.n.aa@m.titech.ac.jp>.

\begin{abstract}
Authors developed concrete using seawater as mixing water. A combination of sea water, ordinary portland cement, ground granulated blast-furnace slag, fly ash, silica fume, and a special chemical admixture containing calcium nitrite was adopted to densify concrete. This concrete is hereafter referred to as "concrete with seawater". This technology not only improves the performance of concrete but also shortens the material transportation process and reduces cost and $\mathrm{CO} 2$ emission from construction work by effective use of seawater when producing concrete in a region where fresh water is not readily available, such as isolated islands and coastal areas. Furthermore, authors developed methods of producing concrete using by-product aggregates such as large uncrushed concrete debris from the earthquake disaster or steel making slag. Especially when using large uncrushed concrete debris, preplaced aggregate concrete method and post-packed concrete method were adopted to reduce processing time and cost by using as much uncrushed concrete debris as possible. This paper describes practical experiments to which we applied these production methods using seawater and by-product aggregates to build concrete blocks for ports and harbors and a pavement for a steel making plant.
\end{abstract}

\section{INTRODUCTION}

Treatment of large amounts of waste from the Great East Japan Earthquake Disaster has become a problem. This research focused on reutilization of concrete debris from concrete structures damaged by the earthquake. Fast and efficient processing is sought in the affected areas to reduce processing time and cost by using as much uncrushed concrete debris as possible. Additionally, it is expected that using seawater as the mixing water will shorten construction time and improve endurance by development of 
early and long-term strength. Thus, we developed methods of producing concrete using large uncrushed concrete debris and seawater, applying the pre-placed aggregate concrete method and the post-packed concrete method. This paper describes results of practical experiments applying these production methods to concrete blocks for ports and harbors.

Steel slag hydrated matrix (SSHM) is a technology that has been developed as a substitute for concrete using steel making slag, ground granulated blast furnace slag powder, and alkaline activator. SSHM, which enable to make efficient use of by-products from steel making plants, has been applied for artificial stone and non-reinforced concrete block for port and harbor. On the other hand, using seawater and special admixture which contains calcium nitrite make concrete denser to develop its early age strength and durability. Authors tried to apply SSHM by using seawater to a pavement in a steel making plant.

\section{BLOCKS USING CONCRETE DEBRIS}

Outline of production method. Large uncrushed concrete debris as coarse aggregate cannot be easily placed into a mixer, so we adopted two methods using separately mixed mortar.

The pre-placed aggregate concrete method or pre-packed concrete method is a method of placing grouting mortar from a grouting pipe inserted into formwork after placing of concrete debris. This method is applicable to structures of complicated shape because it is easy to confirm the situation of concrete debris prior to placing grouting mortar. The grouting mortar requires high segregation resistance and high fluidity. Figure 1 outlines the pre-placed aggregate concrete method using concrete debris.

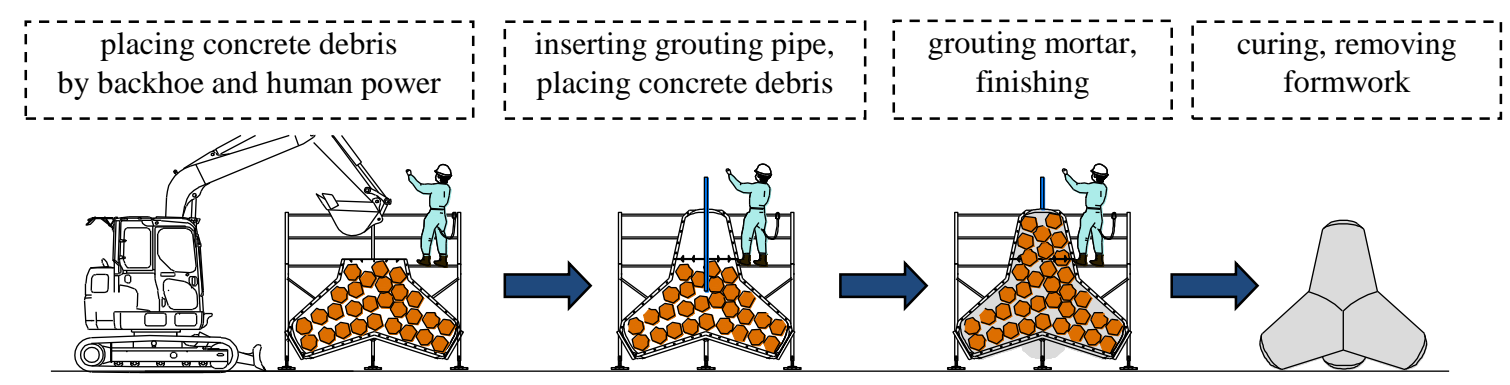

Figure 1. Pre-placed aggregate concrete method

In the post-packed concrete method, concrete debris is placed into mortar cast into formwork in advance. This method is applicable to structures of simple shape, like rectangular blocks because it is difficult to verify visually the filling situation of concrete debris in mortar cast in advance. However, relatively low fluidity mortar can be used, which simplifies this method. Figure 2 outlines the post-packed concrete method using concrete debris.

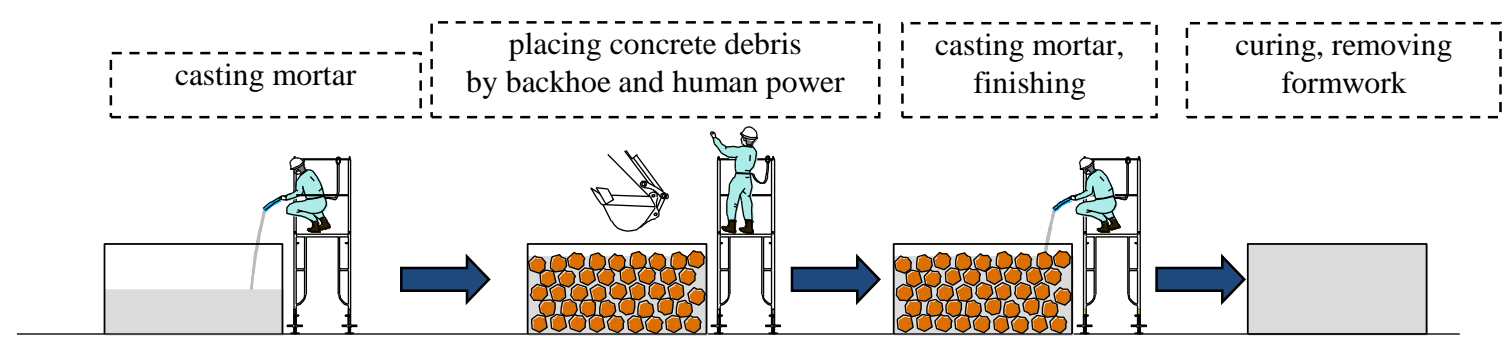

Figure 2. Post-packed concrete method 
Object structure. Table 1 shows cases of the operations. Object blocks for ports and harbors are wavedissipating blocks (25ton, height $3.3 \mathrm{~m} \times$ breadth $3.94 \mathrm{~m}$ ), foot protection blocks (40ton, height $1.5 \mathrm{~m} \mathrm{x}$ breadth $3.0 \mathrm{~m} \times$ length $4.0 \mathrm{~m}$ ) and retaining walls (height $3.0 \mathrm{~m} \times$ breadth $1.5 \mathrm{~m} \times$ length $5.0 \mathrm{~m}$ ), each of unreinforced concrete structure and design strength is $18 \mathrm{~N} / \mathrm{mm} 2$. The post-packed concrete method was adopted for the foot protection blocks, and the pre-placed aggregate concrete method for the wavedissipating blocks and the retaining walls, whose filling situation of concrete debris cannot be confirmed later because of their complicated and narrow shapes. For comparison, the foot protection blocks and wave-dissipating blocks are also produced by mixing concrete using crusher-run (maximum size 40mm) made from concrete debris as coarse aggregate (hereinafter called recycled concrete). As binder materials, Portland blast furnace slag cement was used for each object. Additionally, fly ash (coal ash) which is produced by a coal power station for producing the retaining walls. The dedicated site plant was built to mix mortar and concrete.

Table 1. Object structure and production method

\begin{tabular}{|c|c|c|c|}
\hline Object structure & Production method & Mixing water & Binder \\
\hline Wave-dissipating blocks & $\begin{array}{c}\text { Pre-placed aggregate } \\
\text { concrete }\end{array}$ & Sea water / Fresh water & $\begin{array}{c}\text { Portland blast-furnace } \\
\text { slag cement }\end{array}$ \\
\cline { 2 - 4 } & Mixing concrete & Sea water & $\begin{array}{c}\text { Portland blast-furnace } \\
\text { slag cement }\end{array}$ \\
\hline Foot protection blocks & Post-packed concrete & Sea water / Fresh water & $\begin{array}{c}\text { Portland blast-furnace } \\
\text { slag cement }\end{array}$ \\
\cline { 2 - 4 } & Mixing concrete & Sea water & $\begin{array}{c}\text { Portland blast-furnace } \\
\text { slag cement }\end{array}$ \\
\hline Retaining walls & Pre-placedaggregate \\
concrete & Sea water & $\begin{array}{c}\text { Portland blast-furnace } \\
\text { slag cement and coal ash }\end{array}$ \\
\hline
\end{tabular}

Materials and mix proportion. Concrete debris of size $200-500 \mathrm{~mm}$ was used so that it could be carried by backhoe and handled by human power, and because it was necessary to minimize the crushing process to effectively reuse the huge quantity of concrete debris from the earthquake disaster. The origin of the concrete debris was concrete caissons damaged by the tsunami disaster, and then broken by concrete breakers. Figure 3 shows the concrete debris, and table 2 shows its properties. For reference, the quality of 'recycled aggregate class L' provided in the Japan Industrial Standards (JIS A 5023) is shown in table 2 adscript.

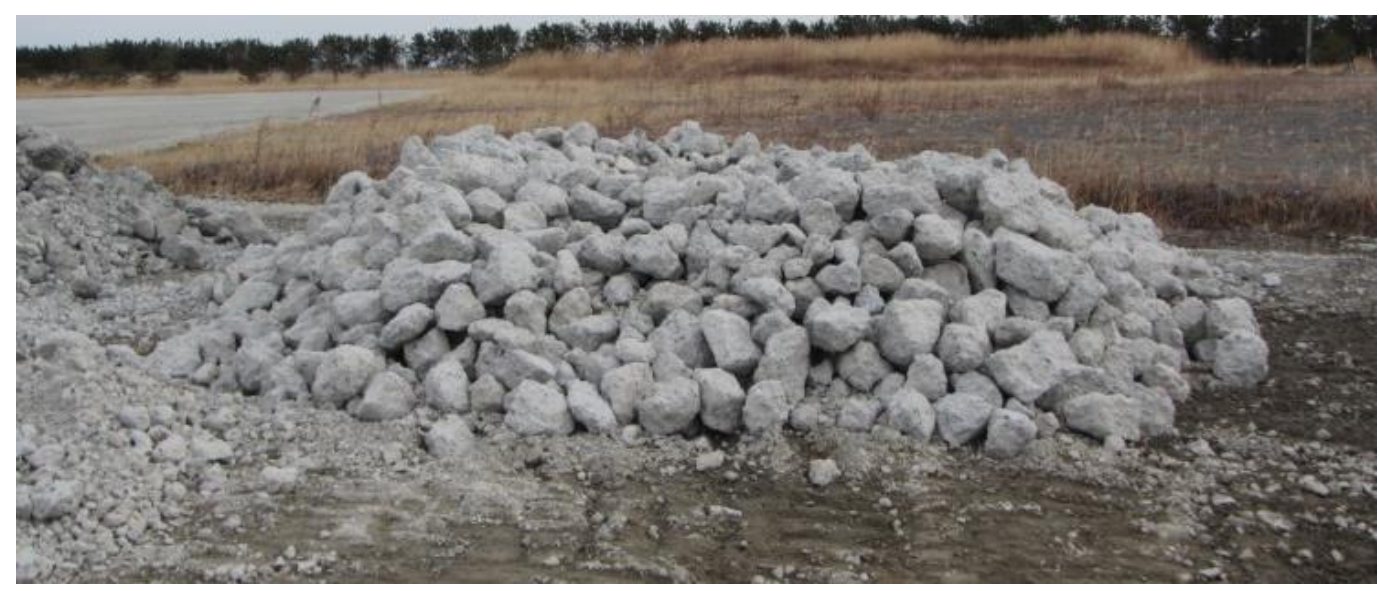

Figure 3. Concrete debris 
Table 2. Properties of concrete debris

\begin{tabular}{|c|c|c|}
\hline Parameter & Property & $\begin{array}{c}\text { (Reference) Standard of Recycled } \\
\text { Course Aggregate Class L (JIS A 5023) }\end{array}$ \\
\hline Particular diameter $(\mathrm{mm})$ & $200-500$ & $5-25$ \\
\hline Density $\left(\mathrm{g} / \mathrm{cm}^{3}\right)$ & 2.37 & 7 or less \\
\hline Absorption $(\%)$ & 7.18 & - \\
\hline Compressive strength $\left(\mathrm{N} / \mathrm{mm}^{2}\right)$ & 37.2 & \\
\hline
\end{tabular}

Table 3. describes the materials used for the mortar and concrete. Portland blast-furnace slag cement type $\mathrm{B}$ was used as the cement. Seawater or fresh water was used as the mixing water of the mortar, and fresh water was used as the mixing water of the concrete. In order to suppress shrinkage cracks, expansive additive was used, and in order to ensure the integrity of mortar and concrete debris, foaming agent (aluminum powder) was used.

Table 3. Materials of mortar and concrete

\begin{tabular}{|c|c|c|c|}
\hline Material & Description & Code & Abstract Specification \\
\hline \multirow[t]{2}{*}{ Water } & Fresh water & \multirow[t]{2}{*}{$\mathrm{W}$} & Tap water \\
\hline & Sea water & & Density $1.03 \mathrm{~g} / \mathrm{cm}^{3}$, Chloride ion content $1.88 \%$ \\
\hline \multirow[t]{3}{*}{ Binder (B) } & $\begin{array}{l}\text { Portland blast-furnace } \\
\text { slag cement type B }\end{array}$ & $\mathrm{C}$ & Density $3.04 \mathrm{~g} / \mathrm{cm}^{3}$ \\
\hline & Expansive additive & Ex & $\begin{array}{l}\text { Calcium oxide type, } \\
\text { Density } 3.16 \mathrm{~g} / \mathrm{cm}^{3}\end{array}$ \\
\hline & Coal ash & FA & $\begin{array}{c}\text { Washed coal ash, Density } 2.21 \mathrm{~g} / \mathrm{cm}^{3}, \\
\text { Average particle size } 28 \mu \mathrm{m}, \\
\text { Water content } 18.2 \%\end{array}$ \\
\hline Coarse aggregate & $\begin{array}{l}\text { Recycled crusher-run from } \\
\text { concrete debris }\end{array}$ & G & $\begin{array}{c}\text { Density } 2.20 \mathrm{~g} / \mathrm{cm}^{3}, \\
\text { Absorption } 12.4 \%, \\
\text { Particular diameter } 40 \mathrm{~mm} \text { or less }\end{array}$ \\
\hline Fine aggregate & Crushed sand & $\mathrm{S}$ & $\begin{array}{c}\text { Density } 2.66 \mathrm{~g} / \mathrm{cm}^{3}, \\
\text { Absorption coefficient } 1.53 \% \text {, } \\
\text { F.M. } 2.75\end{array}$ \\
\hline \multirow[t]{3}{*}{ Admixture } & Forming agent & $\mathrm{AL}$ & Specialty aluminum powder \\
\hline & Super plasticizer & SP & Polycarboxylate type compound \\
\hline & Air entraining agent & $\mathrm{AE}$ & Resinate type surface-activating agent \\
\hline
\end{tabular}

Table 4 shows the mix proportions of the mortar and concrete. The W/B of the mortar for the wave-dissipating blocks was $40.0 \%$, and for the foot protection blocks it was $45.0 \%$. The content of aluminum powder to satisfy the targeted expansive rate was $40 \mathrm{~g} / \mathrm{m}^{3}$. The content of expansive additive was $40 \mathrm{~kg} / \mathrm{m}^{3}$ replaced by cement for mortar based on standard usage. 
Table 4. Mix proportions and properties of mortar and concrete

\begin{tabular}{|c|c|c|c|c|c|c|c|c|c|c|c|c|c|c|}
\hline \multirow[t]{3}{*}{ Type } & \multirow{3}{*}{$\begin{array}{l}\text { Mixing } \\
\text { Water }\end{array}$} & \multirow{3}{*}{$\begin{array}{l}\mathrm{W} / \mathrm{B} \\
(\%)\end{array}$} & \multirow[t]{3}{*}{$\mathrm{S} / \mathrm{B}$} & \multirow{3}{*}{$\begin{array}{l}\mathrm{s} / \mathrm{a} \\
(\%)\end{array}$} & \multicolumn{7}{|c|}{ Unit weight $\left(\mathrm{kg} / \mathrm{m}^{3}\right)$} & \multirow{3}{*}{$\begin{array}{c}\text { Flow } \\
\text { Time } \\
\text { (seconds) }\end{array}$} & \multirow{3}{*}{$\begin{array}{l}\text { Slump } \\
(\mathrm{cm})\end{array}$} & \multirow{3}{*}{$\begin{array}{c}\text { Air } \\
\text { Content } \\
(\%)\end{array}$} \\
\hline & & & & & \multirow[t]{2}{*}{$\mathrm{W}$} & \multicolumn{3}{|c|}{$\mathrm{B}$} & \multirow[t]{2}{*}{$\mathrm{S}$} & \multirow[t]{2}{*}{$\mathrm{G}$} & \multirow[t]{2}{*}{$\mathrm{Al}$} & & & \\
\hline & & & & & & $\mathrm{C}$ & Ex & FA & & & & & & \\
\hline \multirow{2}{*}{$\begin{array}{l}\text { Mortar for wave- } \\
\text { dissipating blocks } \\
\text { (pre-placed } \\
\text { aggregate concrete) }\end{array}$} & Seawater & 40.0 & 1.7 & - & 263 & 618 & 40 & - & 1119 & - & 0.04 & 58.3 & - & 10.0 \\
\hline & $\begin{array}{l}\text { Fresh } \\
\text { water }\end{array}$ & 40.0 & 1.7 & - & 263 & 618 & 40 & - & 1119 & - & 0.04 & 49.2 & - & 10.7 \\
\hline \multirow{2}{*}{$\begin{array}{l}\text { Mortar for foot } \\
\text { protection method } \\
\text { (post-packed } \\
\text { concrete) }\end{array}$} & Seawater & 45.0 & 1.7 & - & 286 & 595 & 40 & - & 1080 & - & 0.04 & 33.0 & - & 9.0 \\
\hline & $\begin{array}{l}\text { Fresh } \\
\text { water }\end{array}$ & 45.0 & 1.7 & - & 286 & 595 & 40 & - & 1080 & - & 0.04 & 31.4 & - & 9.7 \\
\hline $\begin{array}{c}\text { Mortar for retaing } \\
\text { walls (pre-placed } \\
\text { aggregate concrete) }\end{array}$ & Seawater & 40.0 & 1.4 & - & 284 & 600 & 40 & 71 & 995 & - & 0.04 & 47.5 & - & 8.9 \\
\hline Recycled concrete & $\begin{array}{l}\text { Fresh } \\
\text { water }\end{array}$ & 54.7 & - & $46.4^{*}$ & 175 & 320 & - & - & 269 & 1303 & - & - & 11.0 & 5.6 \\
\hline
\end{tabular}

* counting $35 \%$ of recycled crusher-run (particle diameter $5 \mathrm{~mm}$ or less) fine aggregate

Quality control. Table 5 shows the target performance of the mortar. According to the Standard Specification for Concrete Structure "Materials and Construction", the standard flow time (using a Pfunnel) of the mortar for the pre-placed aggregate concrete should be taken as 16 - 20 seconds for a minimum coarse aggregate size of $15 \mathrm{~mm}$. However, in this case, the coarse aggregate size was 200 $500 \mathrm{~mm}$, to the flow time was targeted at $30-60$ seconds. The air content of the mortar was targeted at 8 $12 \%$, and the air content of concrete was targeted at $5.5 \pm 1.5 \%$, assuming the concrete blocks were subjected to freezing and thawing.

Table 5. Targeted performance of mortar

\begin{tabular}{|c|c|}
\hline Test Item (Method) & Targeted Performance \\
\hline Flow time (JSCE F 521) & $30-60$ seconds \\
\hline Air content (JS A 1128) & $8.0-12.0 \%$ \\
\hline Bleeding ratio (JSCE F 522) & $3 \%$ or less at 3 hours \\
\hline Expanding ratio (JSCE F 522) & $2-5 \%$ \\
\hline
\end{tabular}

Compressive strength was evaluated using two types of specimen. One was cast in a steel mold $(\varphi 150 \mathrm{x}$ height $300 \mathrm{~mm}$ ) by the pre-placed aggregate and post-packed concrete methods using concrete debris of particle size about $40 \mathrm{~mm}$ (hereinafter called $\varphi 150 \mathrm{~mm}$ specimen, figure 4$)$. The other type comprised core samples $(\varphi 150 \mathrm{x}$ heights $300 \mathrm{~mm})$ of concrete blocks (cube $800 \mathrm{~mm}$ on a side) made by the pre-placed aggregate and post-packed concrete methods using concrete debris of particle size 200 - 500mm (hereinafter called core specimen, figure 5).

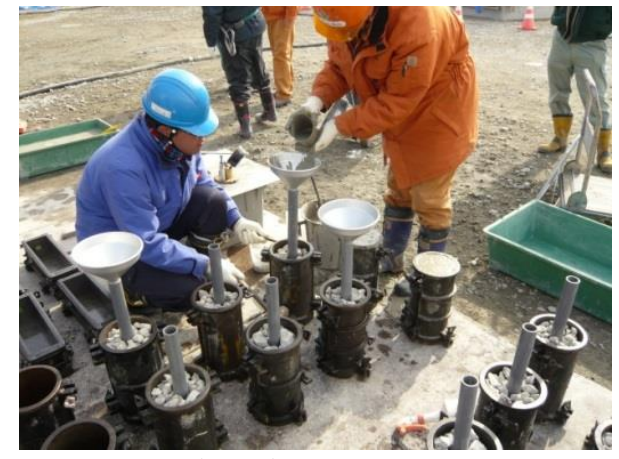

(a) Pre-placed aggregate concrete

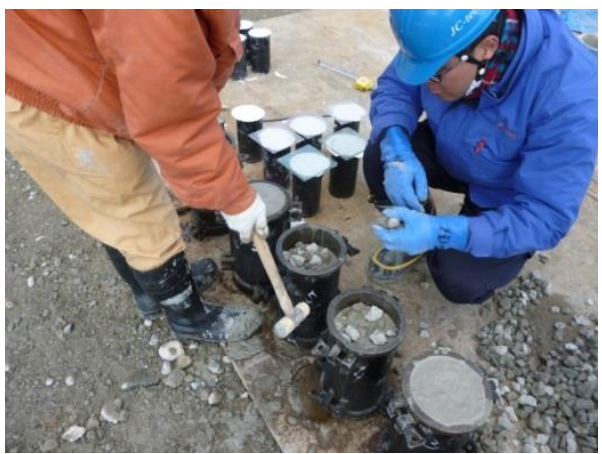

(b) Post-packed concrete

Figure 4. Casting of $\varphi 150 \mathrm{~mm}$ specimens 


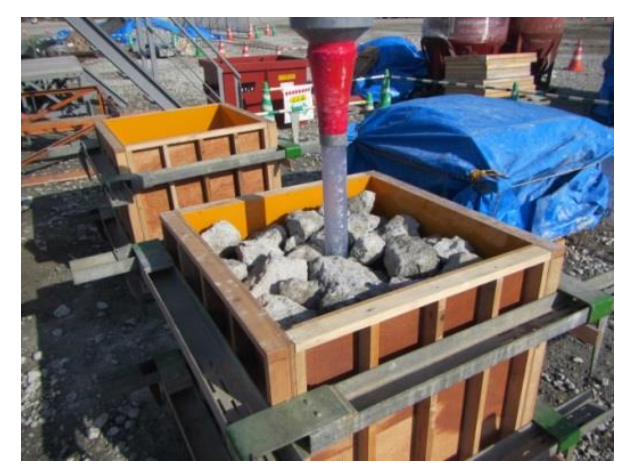

(a) Casting block (pre-placed aggregate concrete)

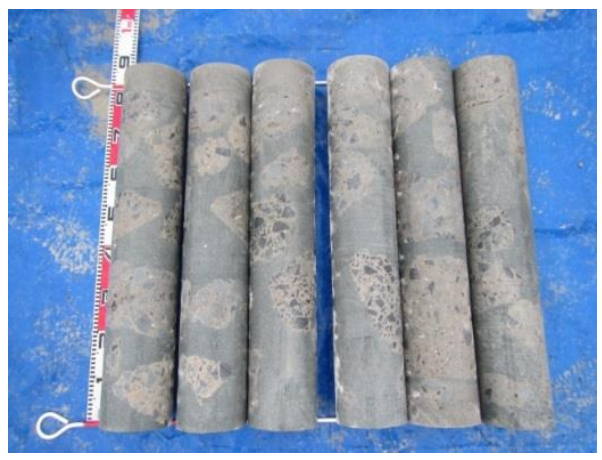

(b) Sampling core

Figure 5. Manufacturing core specimens

\section{Filling situations of mortar}

Figure 6 shows situations of casting the products. Figure 7 shows the appearances of the products after formwork was removed. The mortar filled enough and no voids were found on the product surfaces as a result of controlled fluidity of mortar (flow time between 30 - 60 seconds).

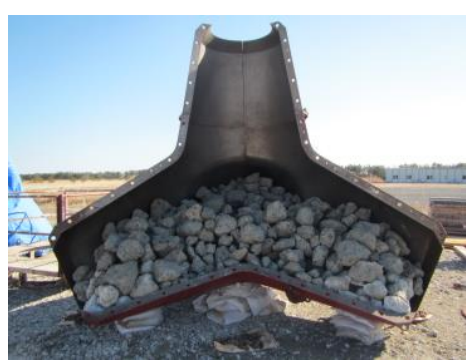

(a) Wave-dissipating block (preplaced-aggregate concrete)

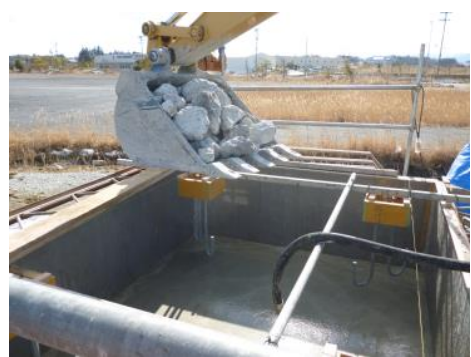

(b) Foot protection block (post-packed concrete)

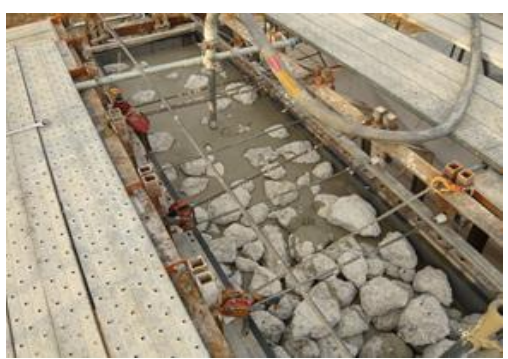

(c) Retaining wall

(preplaced-aggregate concrete)

\section{Figure 6. Production procedures}

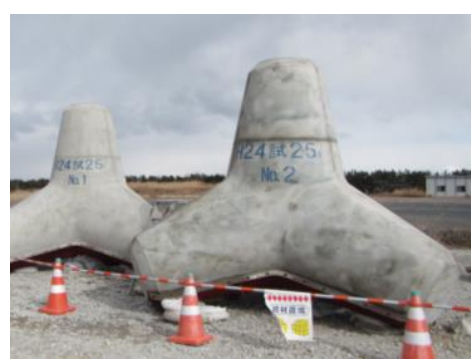

(a) Wave-dissipating block (preplaced-aggregate concrete)

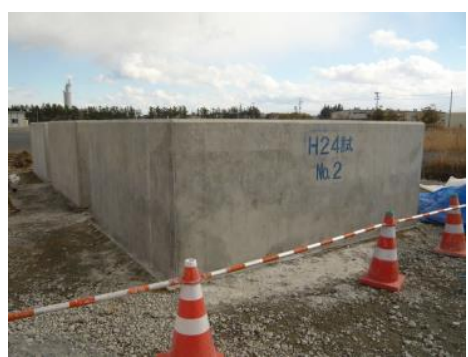

(b) Foot protection block (post-packed concrete)

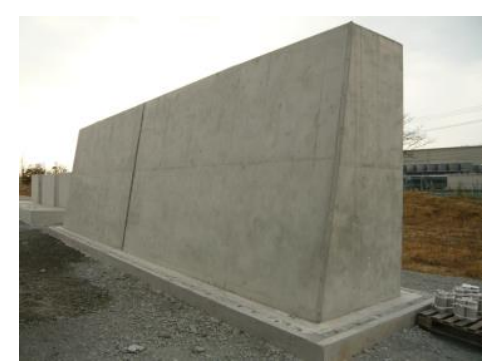

(c) Retaining wall

(preplaced-aggregate concrete)

\section{Figure 7. Appearance of the products}

Compressive strength. Figure 8 to figure 10 show the results of compressive strength tests. The compressive strength of the fresh-water-mixed concrete exceeded the design strength $\left(18 \mathrm{~N} / \mathrm{mm}^{2}\right)$ at 28 days. However, that of the sea-water-mixed concrete exceeded it at 7 days. At 28 days, the compressive strength of the wave-dissipating blocks (W/B $40.0 \%$, sea-water-mixed) was $30 \mathrm{~N} / \mathrm{mm}^{2}$ or over, and that of 
the foot-protection blocks (W/B $45.0 \%$, sea-water-mixed) was $25 \mathrm{~N} / \mathrm{mm}^{2}$ or over. Even in the case of added coal ash (retaining walls, W/B 40.0\%, sea-water-mixed), the compressive strength at 35 days was almost equal to that of the case without coal ash (wave-dissipating blocks) at 28 days.

For both the wave dissipating block and the foot-protection block made from sea-water-mixed mortar, the compressive strengths were higher than for those made from fresh-water-mixed mortar. The strength increase was especially large at early age.

For recycled concrete, strength increase compared to that at 7 days was 1.5 times at 28 days and 2.0 times at 91 days. By contrast, strength increases of the pre-placed aggregate and post-packed concrete with seawater-mixed mortar were lower: $1.2-1.3$ times at 28 days and, $1.3-1.5$ times at 91 days. The reasons of this are thought to be that the compressive strength of pre-placed aggregate and post-packed concrete using concrete debris of large size depends on the strength of the interface between the concrete debris and the mortar or that of the concrete debris itself, and the long-term strength increase of the sea-watermixed mortar tends to be moderate, not showing a remarkable increase in early age.

For the $\varphi 150 \mathrm{~mm}$ specimen with sea-water-mixed mortar, the strength increase compared to that of the fresh-water-mixed mortar tended to be higher than that for the core specimen. Furthermore, though the compressive strengths of the post-packed concrete for the $\varphi 150 \mathrm{~mm}$ specimen and the core specimen are similar, for the pre-placed aggregate concrete, the strength of the $\varphi 150 \mathrm{~mm}$ specimen was higher than that of the core specimen. It is thought that the quantity and location of concrete debris in the core specimens, and the randomness of strength of the concrete debris, influence the strength of the core specimen, because the size of the concrete debris (200 - 500mm diameter) is larger than the size of the core $(150 \mathrm{~mm}$ diameter).

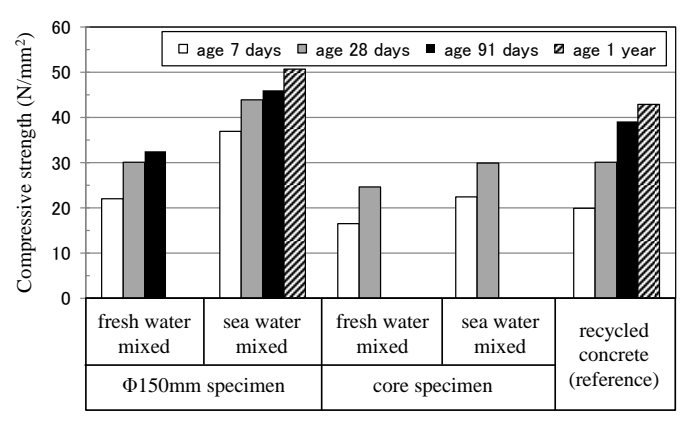

Figure 8. Compressive strength of wavedissipating blocks (preplaced-aggregate concrete)

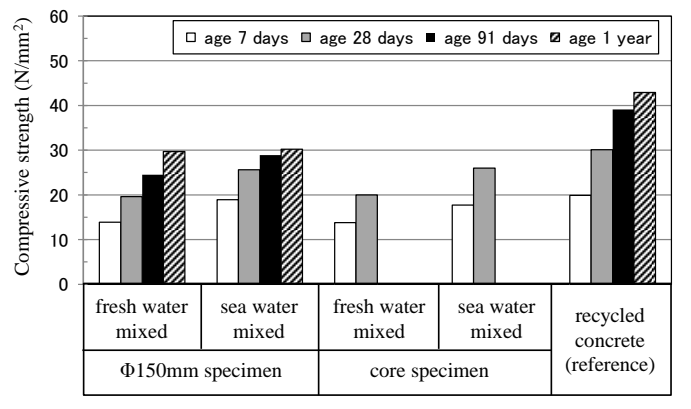

Figure 9. Compressive strength of foot protection blocks (post-packed concrete)

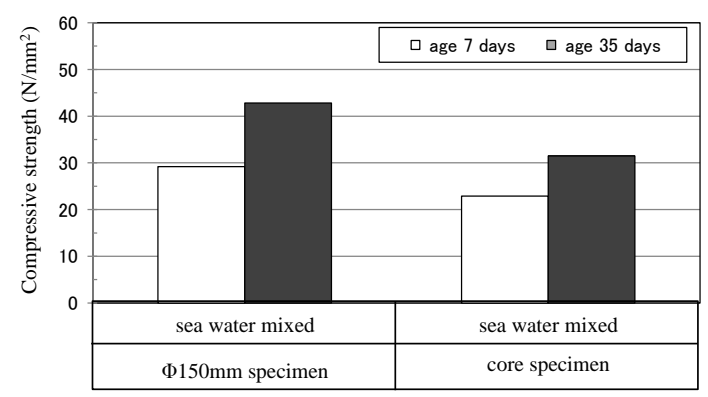

Figure 10. Compressive strength of retaining walls (preplaced-aggregate concrete) 


\section{A PAVEMENT USING STEEL MAKING SLAG}

Experimental study. For pavement materials, Performances as workability, bending strength, durability and abrasion resistance required. Table 6. shows target qualities of SSHM on this experiment. Table 7. shows materials of SSHM. Portland cement was used as alkaline activator, and super plasticizer which has remarkable dispersibility was used for admixture for seawater-mixed SSHM. In addition, special admixture which contains calcium nitrite was used for a case of seawater-mixed SSHM. Table 8. shows test items. Behaviors of fresh concrete, bending and compressive strength of hardened concrete have been tested. Table 9 shows mix proportions and results of fresh concrete tests.

Table 6. Target Qualities

\begin{tabular}{|c|c|}
\hline Item & Target value \\
\hline Slump flow & $50 \pm 10 \mathrm{~cm}$ \\
& (Slump $21 \pm 2.5 \mathrm{~cm}$ ) \\
\hline Air content & $5.0 \pm 1.5 \mathrm{~cm}$ \\
\hline $\begin{array}{c}\text { Bending strength } \\
\text { (Age 7 days) }\end{array}$ & $\begin{array}{c}\text { Specified strength } 4.9 \mathrm{~N} / \mathrm{mm}^{2} \\
\text { (Required strength } 5.64 \mathrm{~N} / \mathrm{mm}^{2} \text { ) }\end{array}$ \\
\hline
\end{tabular}

Table 7. Materials of SSHM

\begin{tabular}{|c|c|c|}
\hline Description & Code & Specification \\
\hline Tap water & W & $\mathrm{Cl}^{-}$content $1.88 \%$ \\
\hline Seawater & BS & Density $2.86 \mathrm{~g} / \mathrm{cm}^{3}$ \\
\hline $\begin{array}{c}\text { Ground granulated } \\
\text { blast-furnace slag }\end{array}$ & NP & Density $3.15 \mathrm{~g} / \mathrm{cm}^{3}$ \\
\hline Portland cement & $\mathrm{S}$ & Density $3.78 \mathrm{~g} / \mathrm{cm}^{3}$ \\
\hline $\begin{array}{c}\text { Steel making slag } \\
\text { fine aggregate }\end{array}$ & $\mathrm{G}$ & $\begin{array}{c}\text { Maximum diameter } 25 \mathrm{~mm}, \\
\text { Density } 3.44 \mathrm{~g} / \mathrm{cm}^{3}\end{array}$ \\
\hline $\begin{array}{c}\text { Steel making slag } \\
\text { coarse aggregate }\end{array}$ & AN & $\begin{array}{c}\text { Contains calcium nitrite, } \\
\text { Density } 1.30 \mathrm{~g} / \mathrm{cm}\end{array}$ \\
\hline $\begin{array}{c}\text { Special admixture for } \\
\text { seawater-mixed concrete }\end{array}$ & SP1 & $\begin{array}{c}\text { Contains polycarboxylate } \\
\text { Contains polycarboxylate } \\
\text { (For seawater-mixed SSHM) }\end{array}$ \\
\cline { 2 - 3 } & $\mathrm{SP} 2$ & \begin{tabular}{c} 
\\
\hline
\end{tabular} \\
\hline
\end{tabular}

Table 8. Test Items

\begin{tabular}{|c|c|c|}
\hline Item & Standard & Specification \\
\hline Slump and slump flow & JIS A 1101, JIS A 1150 & \\
\hline Air content & JIS A 1128 & \\
\hline Temperature & & $100 * 100 * 400 \mathrm{~mm}$, seal curing \\
\hline Bending strength & JIS A 1106 & $\varphi 100 * 200 \mathrm{~mm}$, seal curing \\
\hline Compressive strength & JIS A 1108 & 0 \\
\hline
\end{tabular}

Table 9. Mixture Proportions and Results of Fresh Concrete Tests

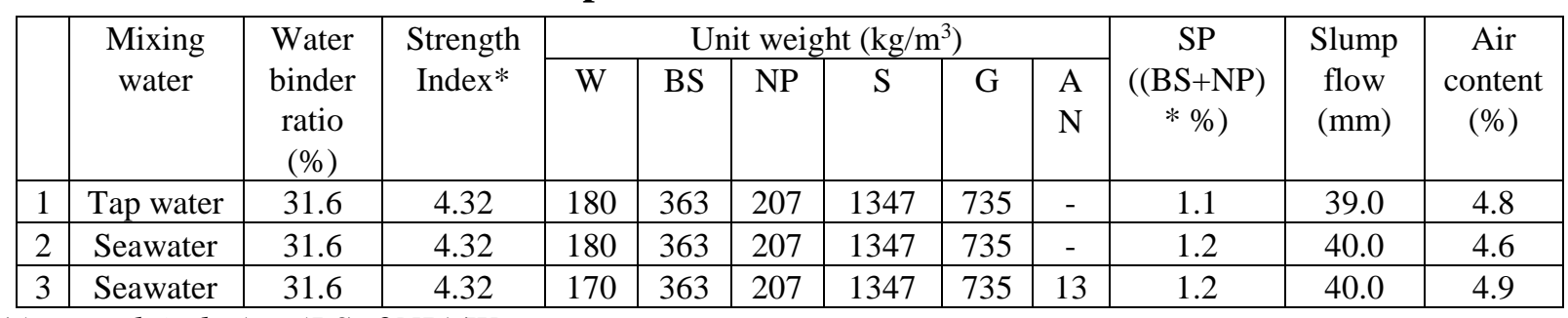

$*($ strength index $)=(B S+2 N P) / W$ 
Figure 11 and figure 12 show the results of compressive and bending strength respectively. Compressive strength increased by using seawater as mixing water, even more by adding special admixture. However, bending strengths of the cases using seawater and adding special admixture were approximately equal to the case using fresh water at the age 7 days. It is expected that using seawater and adding special admixture increase abrasion resistance, because higher compressive strength obtained, the higher abrasion resistance become.

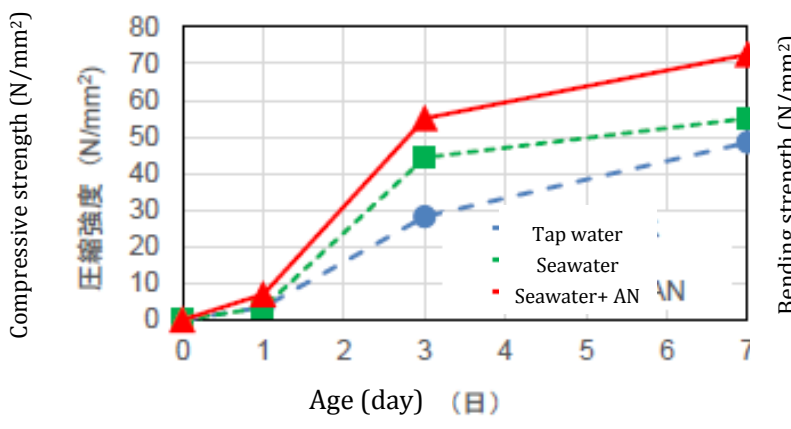

Figure 11. Compressive Strength

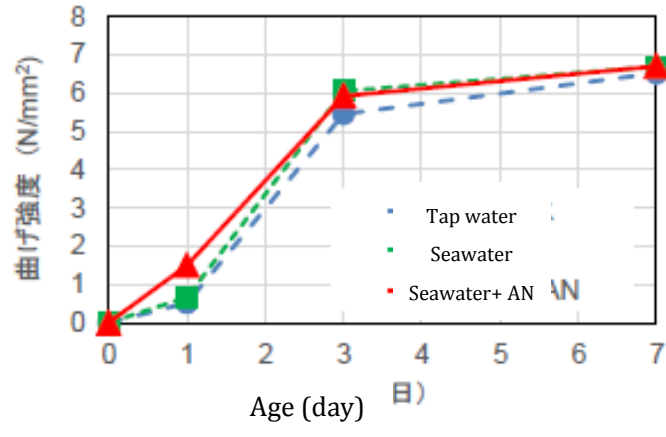

Figure 12. Bending Strength

\section{Construction experiment}

Authors applied seawater-mixed SSHM to a pavement in a steel making plant and evaluated quality and stability. The objective pavement was $25 \mathrm{~cm}$ thick and $1000 \mathrm{~m}^{2}$ large in area.

Materials of SSHM were same as mentioned in Table 7. Seawater was obtained by pumping up from a sea bank in the steel making plant. Batch mixer was $1 \mathrm{~m}^{3}$ forced mixing, double-horizontal- axis type. Mix proportion of SSHM was revised as Table 10. because of a size distribution change of steel making slag aggregate.

\section{Table 10. Mixture Proportions for the Pavement}

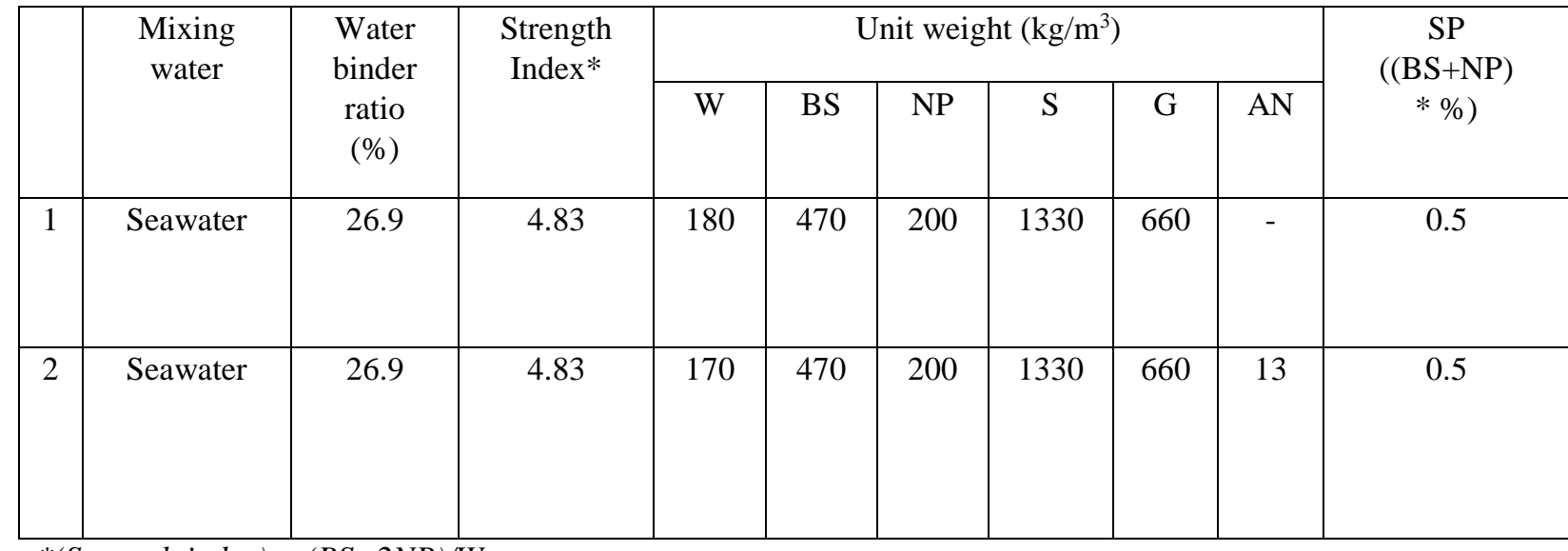

$*($ Strength index $)=(B S+2 N P) / W$

Figure 13 shows the result of quality control test. Figure 14 shows situation of slump flow test, figure 15 . shows situation of casting the pavement, and figure 16 shows appearance of the pavement after construction. According to the results, seawater-mixed SSHM satisfied target qualities of the pavement and caused neither surface cracking nor other defects. 

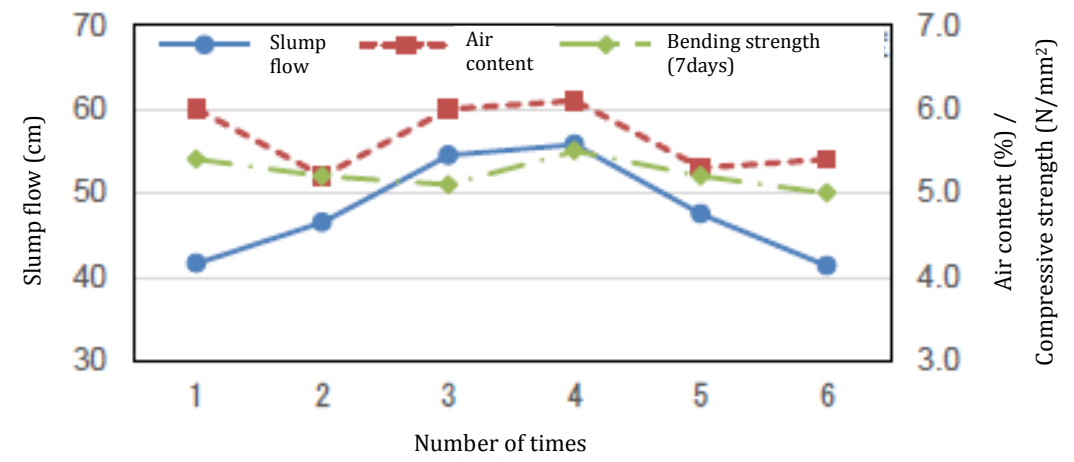

Figure 13. Result of Quality Control Test

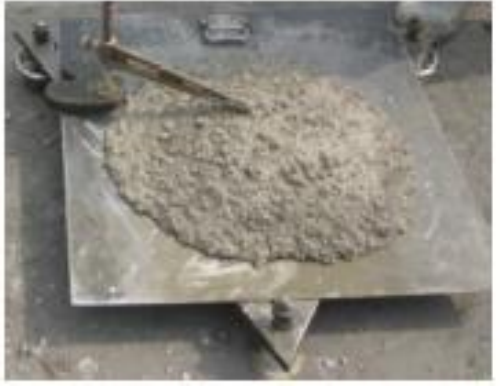

Figure 14. Situation of the Slump Flow Test Construction.

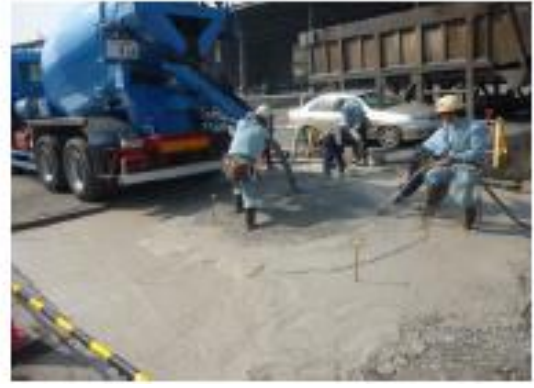

Figure 15. Situation of Casting the Pavement

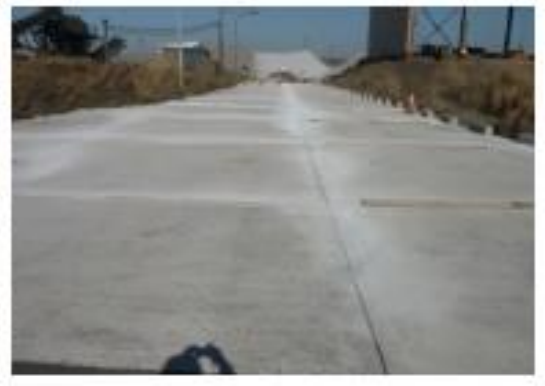

Figure 16. Appearance of Pavement After

\section{SUMMARY}

In this research, a technology of concrete using seawater and by-products (uncrushed concrete debris, steel making slag) has been established by the experimental study and the construction experiment. It is expected that using seawater shortens construction term and increases abrasion resistance because of development of compressive strength. Authors are going to expand the application of this technology to reinforced concrete structure.

\section{ACKNOWLEDGMENTS}

The practical experiment using concrete debris was conducted as "the application of the technology in the disaster relief work of northeast ports" publicly-offered by Tohoku Regional Bureau Ministry of Land, Infrastructure and Transport. Technical support by Nikki Kensetsu Co., ltd. and Fudo Tetra Corporation was necessary to conduct the experiment producing concrete blocks for ports and harbors.

\section{REFERENCES}

Katano, K., Nobufumi,T., et al. (2015). Development of Concrete by Using Sea Water and Concrete Debris from Earthquake Disaster, CONMAT'15 The Fifth International Conference on Construction Materials: Performance, Innovations and Structural Implications, paper No.: 108

Katano, K., Nobufumi,T., et al. (2013). Properties and application of concrete made with sea water and un-washed sea sand. SCMT4 4th International Conference on Sustainable Construction Materials and Technologies, paper No.: e172.

Nobufumi,T., Katano, K., et al. (2014). Production of concrete blocks for port by using seawater and concrete debris produced by earth quake disaster, Proceedings of the Japan Concrete Institute, Vol. 36, pp. $1534-1539$. 